\title{
Çocukluk Çağı Henoch-Schönlein Purpuralı Hastaların Klinik Analizleri
}

\section{The Clinical Analysis of Childhood Henoch-Schönlein Purpura Patients}

$$
\begin{array}{r}
\text { Cihangir Akgün, Sinan Akbayram*, Avni Kaya*, Hayrettin Temel*, Salim Bilici**, } \\
\text { Fesih Aktar*, Șükrü Arslan*** }
\end{array}
$$

Yüzüncü Yıl Üniversitesi Tıp Fakültesi Araștırma Hastanesi, Çocuk Sağlığı ve Hastalıkları Anabilim Dalı, Çocuk Nefroloji Bilim Dalı, *Çocuk Sağlığı ve Hastalıkları Ana Bilim Dalı, **Çocuk Cerrahisi Anabilim Dalı, Van, Türkiye ***Samsun Ondokuz Mayıs Üniversitesi Tıp Fakültesi Araștırma Hastanesi, Çocuk Sağlığı ve Hastalıkları Anabilim Dalı, Çocuk Nefroloji Bilim Dalı, Samsun, Türkiye

\section{Özet}

Amaç: Henoch-Schönlein purpurası sıklıkla deri, eklem, gastrointestinal sistem ve böbreklerin etkilendiği çocukluk çağının sık rastlanan sistemik bir vaskülitidir. Semptomlarının çok çeșitli olması nedeni ile de Henoch-Schönlein purpurası, çocuk polikliniklerinde takip edilen ve yatıılan hastalıklar için de önemli bir yer tutmaktadır. Amacımız Henoch-Schönlein purpuralı hastaların klinik analizlerinin incelenerek ortaya konulmasıdır.

Gereç ve Yöntem: Polikliniklerimizde Henoch-Schönlein purpurası tanısı almıș 212 hastanın tıbbi kayıtları retrospektif olarak incelendi. Bu hastaların yaș grupları, tanı aldıkları mevsimler, tutulan sistemler, laboratuvar bulguları, verilen tedaviler, olușan komplikasyonlar ve prognozları incelendi. Veri analizi için SPSS 13 istatistik paket programı kullanıldı.

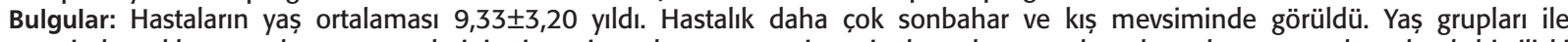
mevsimler, eklem tutulumu, santral sinir sistemi tutulumu, gastrointestinal tutulum ve skrotal tutulum arasında anlamlı bir ilișki mevcut değilken, yaș grupları ile böbrek tutulumu arasında pozitif bir ilișki saptandı.

Sonuç: Hastaların yașları arttıkça tedavi süreleri ve kombine ilaç tedavisine (antihistaminik, non-steroid antiiflamatuvar ve steroid) ihtiyaçları artmaktadır. (Türkderm 2012; 46: 73-7)

Anahtar Kelimeler: Purpura, vaskülit, çocuk, immunglobulin A

\section{Summary}

Background and Design: Henoch-Schonlein purpura is affected often the skin, joints, gastrointestinal tract and kidneys and common systemic vasculitis of childhood. Henoch-Schonlein purpura are many and varied symptoms, also it was followed in children policlinics and hospitalized diseases for an important role. We aimed to determination of the patients with Henoch-Schönlein purpura by examination of their clinical analyses.

Material and Method: The medical records of 212 patients with Henoch-Schönlein purpura in our polyclinics have been retrospectively studied. These patients were analyzed age groups, diagnosed seasons, held systems, laboratory findings, the treatments, complications and prognosis. SPSS 13 statistical software package was used for data analysis.

Results: The mean age of the patients was $9.33 \pm 3.20$ years. The disease was more frequently demonstrated in fall and winter seasons. There was no statistically assosiation between age groups with season, joint involvement, central nerveous system involvement, gastrointestinal system involvement and scrotal involvement but there was a positive correlation between age groups and renal involvement.

Conclusion: The treatment duration increases with the age of the patient and the necessity to use a combined treatment (antihistaminic, non-steroid anti-inflammatory treatment and steroids) increases. (Turkderm 2012; 46: 73-7)

Key Words: Purpura, vasculitis, child, immunoglobulin A

Yazışma Adresi/Address for Correspondence: Dr. Avni Kaya, Yüzüncü Yıl Üniversitesi, Tıp Fakültesi Araștırma Hastanesi, Cocuk Sağlığı ve Hastallkları Ana Bilim Dall, Van, Türkiye Tel.: +90 4322171983 E-posta: avnikaya@gmail.com Geliş Tarihi/Received: 23.02.2011 Kabul Tarihi/Accepted: 11.08 .2011

Türkderm-Deri Hastalıkları ve Frengi Arșivi Dergisi, Galenos Yayınevi tarafından basılımıștır.

Turkderm-Archives of the Turkish Dermatology and Venerology, published by Galenos Publishing. 


\section{Giriş}

Henoch-Schönlein purpurası (HSP) sıklıkla deri, eklem, gastrointestinal sistem (GiS) ve böbreklerin etkilendiği çocukluk çağının sık rastlanan sistemik bir vaskülitidir. Genel toplumda HSP görülme sıklığı çocuklarda yaklaşık 22,1/100.000 çocuk/yıl olarak bildirilmiştir ${ }^{1}$. Erkek çocuklarda kızlara göre 1,5 kat daha sık görülür². Patogenezi tam olarak aydınlatılamamakla birlikte etiyolojide infeksiyonlardan ilaçlara, aşılardan çeşitli besinlere kadar pek çok ajan suçlanmaktadır². Çalışmamızın amacı, hastanemizde tanı konmuş, HSP'li hastaların retrospektif çalışma ile klinik analizlerinin incelenerek ortaya konulmasıdır.

\section{Gereç ve Yöntem}

Bu çalışmaya, Ocak 2004-Ekim 2008 tarihleri arasında Çocuk Sağlığı ve Hastalıkları Anabilim Dalı Pediyatrik Nefroloji polikliniğine, genel pediyatri polikliniğine ve çocuk acil polikliniklerine getirilen ve HSP tanısı almış 212 hasta alındı. Bu hastaların tanısı American College of Rheumatology 1990 yılında HSP için yayınladığı tanı kriterlerine göre kondu (Tablo 1)3. Bu hastaların yaş grupları, tanı aldıkları mevsimler, tutulan sistemler, laboratuvar bulguları, verilen tedaviler, oluşan komplikasyonlar ve prognozları retrospektif olarak incelendi. İzleminde bulguları tamamen iyileşen hastaların bulgularının tekrarı relaps olarak değerlendirildi. Veri analizi için SPSS 13 istatistik paket programı kullanıldı. Sürekli değişkenler için ortalamaları karşılaştırmada Student-t testi kullanıldı. Bu değişkenler arasındaki ilişkiyi belirlemek amacıyla; Pearson korelasyon katsayıları hesaplandı. Kategorik değişkenler arasındaki ilişkiyi belirlemede ise Ki-kare testi kullanıldı. Hesaplamalarda istatistik anlamlılık düzeyi $p<0,05$ olarak alındı.

\section{Bulgular}

Çalışmaya alınan 212 hastanın 121'i erkek $(\% 57,1)$ 91'i ise kızdı $(\% 42,9)$. Erkek/kız oranı 1,33 olarak tespit edildi. Çalışmaya alınanların

\section{Tablo 1. Henoch-Schönlein purpurası tanı kriterleri}

\begin{tabular}{|l|l|}
\hline Döküntü cinsi & palpabl purpura \\
\hline Tanı yaşı & $<20$ yaş \\
\hline Trombositopeni & yok \\
\hline Karın ağrısı tipi & yemeklerden sonra artan \\
\hline Kanlı dışkılama & var \\
\hline Patoloji & arteriol/venül duvarlarında granülosit infiltrasyonu \\
\hline
\end{tabular}

\section{Tablo 2. Sistem tutulum yerleri}

\begin{tabular}{|l|c|c|}
\hline Sistem tutulumu & Hasta sayısı $(\mathbf{n})$ & Yüzde (\%) \\
\hline Deri & 212 & 100 \\
\hline Kas iskelet sistemi & 143 & 67,5 \\
\hline Gastrointestinal sistem & 99 & 46,7 \\
\hline Renal & 48 & 22,6 \\
\hline Skrotal & 2 & 0,9 \\
\hline Santral sinir sistemi & 2 & 0,9 \\
\hline
\end{tabular}

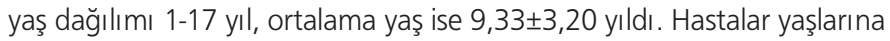
göre 3 gruba ayrıldı I. gruba 0-5 yaş arası olgular, II. gruba 6-10 yaş arası olgular, III. gruba 11-18 yaş olgular alındı (Tablo 4). 1. gruptaki hastaların 14'ü erkek (\%56), 11'i kızdı (\%44). 2. grup hastaların 60'ı erkek $(\% 53,6), 52$ 'si kızı $(\% 46,4)$ ve 3. grup hastaların ise 47'si erkek $(\% 62,7)$, 28 'i kızdı $(\% 37,3)$. Hastaların başvuru esnasındaki mevsimlere göre dağılımı yapıldı. Illkbahar aylarında $48(\% 22,6)$, yaz aylarında 48 $(\% 22,6)$, sonbahar aylarında $63(\% 29,7)$ ve kış aylarında $53(\% 25)$ hasta başvurdu. Hastaların yaş gruplarına göre dağılımı ile mevsimlerle ilişkisi karşılaştııılı ve anlamlı bir ilişki saptanmadı $(p>0,05)$. HSP'li hastaların sistem tutulum yerleri ve sıklığı belirlendi (Tablo 2 ).

Renal tutulumu olan hastaların tamamında hematüri görülürken 29 $(\% 13,7)$ hastada hematüri ve proteinüri birlikte görüldü. Renal tutulumu olan hastalardan 7 'sine $(\% 3,3)$ renal biyopsi uygulandı, $2(\% 0,9)$ hasta biyopsi için ileri merkeze sevk edildi, $1(\% 0,5)$ hastaya ailenin biyopsiyi kabul etmemesi nedeniyle renal biyopsi yapılamadı. Renal biyopsi yapılan $6(\% 2,9)$ hastada diffüz mezengial proliferasyon tespit edilirken $1(\% 0,5)$ hastada klas II lupus nefriti tespit edildi.

Hastaların yaş grupları ile sistem tutulumları arasındaki ilişki incelendi. Buna göre, yaş grupları ile eklem tutulumu, Gis tutulumu, santral sinir sistemi (SSS) tutulumu ve skrotal tutulum ile anlamlı bir ilişki bulunmazken $(p>0,05)$ yaş grupları ile renal tutulum arasında istatistiksel olarak anlamlı bir ilişki saptandı $(p<0,05)$. 1. grupta $3(\% 1,4), 2$. grupta $21(\% 9,9)$, 3. grupta $24(\% 11,3)$ hastada renal tutulum saptandı. Buna göre hasta yaşı arttıkça renal tutulum oranı artmaktaydı. Hastaların cinsiyetleri ile renal tutulum, Gis tutulumu, relaps oranı ve invajinasyon açısından ayrı ayrı istatistiksel analiz yapıldı, ancak hiçbirinde anlamlı bir ilişki saptanmadı ( $p>0,05)$.

Hastaların başvuru esnasında 14'ünde $(\% 6,6)$ invajinasyon mevcuttu. Bunlardan 3 'ü $(\% 1,4)$ inkomplet invajinasyon olarak değerlendirildi. Invajinasyonlu $1(\% 0,5)$ hasta opere edilirken geri kalan $13(\% 6,2)$ hasta klinik izlem esnasında spontan düzeldi. Yaş grupları ile invajinasyon arasındaki ilişki istatistiksel olarak incelendi ancak anlamlı bir ilişki saptanmadı ( $>0,05)$. Hastaların laboratuvar bulguları belirlendi (Tablo 3). Hastaların laboratuvar bulgularıyla sistem tutulumları ve relaps arasındaki ilişki karşılaştırıldı. Hastaların başlangıçtaki lökosit değerlerinin sistem tutulumu ve relaps ile ilişkisi değerlendirildiğinde lökositoz ile renal tutulum ve GiS tutulumu arasında anlamlı bir ilişki saptanırken $(p<0,05)$ diğer sistem tutulumları ve relaps açısından bu anlamlı ilişki gösterilemedi. Hastaların başlangıçtaki trombosit değerlerinin sistem tutulumu ve relaps ile ilişkisi değerlendirildiğinde ne sistem tutulumları ne de relaps açısından istatistiksel olarak anlamlı bir ilişki saptanmadı $(p>0,05)$. Serum IgA düzeyi

\section{Tablo 3. Hastalarımızın laboratuvar bulguları}

\begin{tabular}{|l|c|c|}
\hline & Hasta sayısı (n) & Yüzde (\%) \\
\hline Lökositoz & 54 & 27,4 \\
\hline Trombositoz & 74 & 34,9 \\
\hline Yüksek serum IgA düzeyi & 14 & 6,6 \\
\hline Artmış sedimentasyon hızı & 82 & 38,7 \\
\hline Yüksek CRP düzeyi & 88 & 41,5 \\
\hline Yüksek anti streptolizin O düzeyi & 35 & 16,5 \\
\hline Hepatit B antijeni & 1 & 0,5 \\
\hline Pozitif boğaz kültürü & 9 & 4,2 \\
\hline Pozitif gayta gizli kan & 46 & 21,7 \\
\hline
\end{tabular}


Tablo 4. Hasta yaş grupları ve tedavi grupları dağılımı

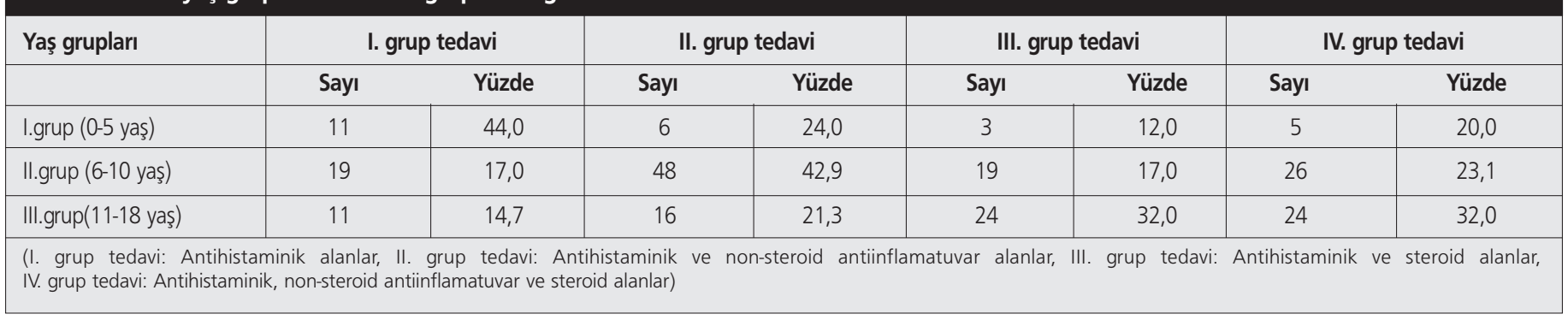

yüksekliği ile GiS tutulumu, renal tutulum ve relaps arasında anlamlı bir ilişki saptanmazken $(p>0,05)$, serum IgA düzeyi yüksek olanlarda eklem tutulumunun daha sık olduğu görüldü ve bu birliktelik istatistiksel olarak anlamlıydı $(p<0,05)$. Serum CRP ve eritrosit sedimantasyon hızı yüksekliği ile Gis tutulumu, eklem tutulumu ve relaps arasında herhangi bir istatistiksel ilişki saptanmazken her ikisinin yüksek düzeyleri ile renal tutulum arasında anlamlı bir ilişki mevcuttu $(p<0,05)$. Sistem tutulumlarının kendi aralarında ve relaps ile istatistiksel ilişkileri araştııldı ve ne GiS tutulumunun eklem tutulumu ile ne de renal tutulum ve relaps ile anlamlı ilişkisi saptandı. Benzer şekilde eklem tutulumu ile renal tutulum veya relaps arasında istatistiksel olarak anlamlı bir ilişki yoktu $(p>0,05)$.

Uygulanan tedaviye göre hastalar sadece antihistaminik alanlar (1. grup), antihistaminik ve non-steroid antiinflamatuvar (NSAii) alanlar (2. grup), antihistaminik ve steroid alanlar (3. grup),ve antihistaminik, NSAii ve steroid alanlar (4. grup), olarak dört gruba ayrılarak tedavi süreleri ve sonuçları ortaya kondu. Tedavi süreleri hastaların klinik durumlarına göre 2 hafta ile 12 hafta arasında değişmekteydi. Hasta grupları ve tedavi grupları dağılımı Tablo 4 'te gösterildi.

Hastaların takiplerinde 182'si $(\% 85,8)$ şifa ile sonuçlanırken, $5(\% 2,4)$ hasta ailenin isteği üzerine ileri merkeze sevk edildi. Yirmi beş $(\% 11,8)$ hasta ise ilk ataktan sonra kontrollere gelmedi. Hastaların 46'sında $(\% 21,7)$ takiplerinde relaps gelişirken $166(\% 78,3)$ hastada ise relaps görülmedi.

\section{Tartışma}

Henoch-Schönlein purpurası, deri döküntüsü, Gis semptomları, eklem ve böbrek tutulumu ile karakterize çocukluk çağının en sık görülen sistemik vaskülitidir4. Erkek çocuklarda kızlara göre 1,5 kat daha sık görülür2. En küçük hastamız 1 yaşında, en büyük hastamız 17 yaşında

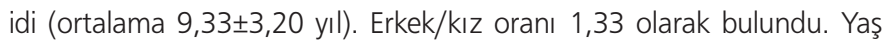
grupları ile eklem tutulumu, GiS tutulumu, SSS tutulumu, skrotal tutulum ile anlamlı bir ilişki bulunmazken renal tutulum arasında istatistiksel olarak anlamlı bir ilişki saptandı. Hasta yaşı arttıkça renal tutulum oranı artmaktaydı. Assadi F5, HSP'nin renal tutulumun büyük çocuk ve erişkinlerde daha fazla olduğunu belirtmiştir. Bir başka çalışmada da benzer şekilde yaş ile birlikte böbrek tutulum sıklığının arttığı gösterilmiştir6. Erişkin yaş grubu ve çocuklarda görülen HSP'nin klinik ve laboratuvar bulgularının karşılaştııılığı bir başka çalışmada da, böbrek tutulumunun erişkinlerde daha sık ve daha şiddetli olduğu bildirilmiştir7. HSP'ye sıklıkla kış aylarında rastlanmaktadır8. Yapılan bir çalışmada vakaların 2/3'ünün sonbahar ve kış aylarında görüldüğü bildirilmiştir9 Çalışmamızda ise vakaların en sık sonbahar aylarında görüldüğü $(\% 29,7)$, bunu kış aylarının takip ettiği saptandı $(\% 25,1)$. Çalışmamızdaki hastaların tamamında (\%100) başvuru esnasında HSP vaskülitine ait deri döküntüsü mevcuttu. Bunlardan $133(\% 62,7)$ tanesine başvuru esnasında deri biyopsisi uygulandı. Tamamında deri tutulumu olduğu gözlendi. Hastalarımızın tamamında deri tutulumunun olmasının sebebi, vakalarımızda HSP tanı kriterleri olarak Ozen S ve ark. tarafından 2006 yılında bildirilen HSP için tanı ölçütlerinin kullanılması ve bu kriterlere göre tanı için palpabl purpuranın zorunlu olmasıdır ${ }^{10}$. Hastalarımızdan 143'ünde $(\% 67,5)$ artralji ve/veya artrit şeklinde eklem tutulumu, $99(\% 46,7)$ hastada invajinasyon, karın ağrısı ve/veya gaytada gizli veya aşikar kan şeklinde Gis tutulumu, $2(\% 0,9)$ hastada SSS tutulumu, $2(\% 0,9)$ hastada skrotal tutulum, $48(\% 22,6)$ hastada hematüri ve/veya proteinüri şeklinde renal tutulum mevcuttu. Değişik çalışmalarda, sistem tutulumları açısından değişik oranlar bildirilmiştir. Fretzayas A ve ark. ${ }^{11}$ HSP'de \%91,8 oranında eklem tutulumu, \%40,5 oranında da Gis tutulumu bildirmişlerdir. Assadi $\mathrm{F}^{5}$ ise, 45 vakalık bir seri ile yaptığı çalışmasında eklem tutulum oranını, \%73,3 Gis tutulum oranını da \%68,6 olarak bildirmiştir. Ülkemizde Peru $\mathrm{H}$ ve ark. yaptıkları bir çalışmada da eklem tutulum oranını \%66, GiS tutulum oranını da \%56 olarak bildirmişlerdir. Aynı çalışmada Gis tutulumu olan 144 vakanın 8 'inde $(\% 5,5)$ invajinasyon geliştiği ve bunların 3'ünün (\%2) opere olduğu geri kalan 5 vakanın steroid tedavisi ile veya spontan düzeldiği bildirilmiştir ${ }^{12}$. Hastalarımızın başvuru esnasında 14'ünde $(\% 6,6)$ invajinasyon mevcuttu. Bunlardan 3'ü $(\% 1,4)$ inkomplet invajinasyon olarak değerlendirildi. İnvajinasyonlu $1(\% 0,5)$ hasta opere edilirken geri kalan $13(\% 6,2)$ hasta klinik izlem esnasında spontan düzeldi. Yaş grupları ile invajinasyon arasındaki ilişki istatistiksel olarak incelendi, ancak anlamlı bir ilişki saptanmadı.

HSP'de SSS tutulumu, böbrek tutulumu gibi hayatı tehdit eden bir durumdur. Baş ağrısı, bilinç değişiklikleri ve konvülsiyonlar en sık görülen nörolojik bulgulardır13. Almanya'da yapılan bir çalışmada HSP'de nörolojik tutulum oranı $\% 2$ gibi çok düşük bulunmuştur ${ }^{14}$ Vakalarımızda SSS tutulumu \%0,9 oranındaydı.

Nong ve ark. ${ }^{4}$ Taywan'da HSP ile ilgili 15 yıllık deneyimlerini sundukları çalışmalarında vakaların büyük çoğunluğunda deri döküntülerinin bacaklarda ve kalçalarda olduğunu bildirmişlerdir. Başka çalışmada ise gövde ve üst ekstremitede döküntü görülme oranı \%35,1 olarak bildirilmiştir ${ }^{15}$. Aynı çalışmada \%9,6 oranında persistan purpura rapor edilmişken bizim vakalarımızın hiç birinde persistan purpuraya rastlanmadı. Vakalarımızın deri tutulumlarını değerlendirdiğimizde hastaların tamamında (\%100) başvuru esnasında bacakta döküntü mevcuttu. Yüz yedi $(\% 50,5)$ hastada gluteal bölgede döküntü görülürken $58(\% 27,4)$ hastada kollarda, $56(\% 26,4)$ hastada ellerde, 29 $(\% 13,7)$ hastada ise gövdede döküntü tespit edildi.

HSP genellikle kendini sınırlayan ve iyi prognozlu bir hastalık olmasına rağmen, böbrek tutulumu morbidite ve mortaliteden büyük oranda sorumludur. Prognozu böbrek tutulumu belirler. Çocukluk yaş grubu HSP'li vakaların yaklaşık \%20-80'inde böbrek tutulumunun görüldüğü bildirilmiştir16,17. Şikago'da yapılan bir çalışmada, HSP'li vakaların $\% 88,6$ 'sında hematüri, $\% 66,7$ 'sinde hematüri ve proteinüri (nefrotik 
düzeyde olmayan), $\% 17,8^{\prime}$ inde nefrotik sendrom, $\% 8,9^{\prime}$ unda akut nefritik sendrom ve \%13,3'ünde nefritik-nefrotik sendrom tespit edilmiştir ${ }^{5}$. Aynı çalışmada hastalığın başlangıcında ve seyri esnasında nefritik-nefrotik sendrom gelişmesinin glomeruler hastalığın şiddetini belirleyen anlamlı bağımsız bir belirteç olduğu sonucuna varılmıştır 5 . Fretzayas A. ve ark. ${ }^{11}$ ise HSP'li hastalarda renal tutulum oranını \%25,7 olarak bulmuşlar ve çalışmalarında böbrek tutulumu olan 19 hastadan 2'sinde kalıc mikroskobik hematüri saptamışlardır. Çalışma grubumuzda renal tutulumu olan hastaların tamamında hematüri görülürken, 29 $(\% 13,7)$ hastada hematüri ve proteinüri birlikte görüldü. Renal tutulumu olan hastalardan 7'sine $(\% 3,3)$ böbrek biyopsisi uygulandı, $2(\% 0,9)$ hasta biyopsi için ileri merkeze sevk edildi, $1(\% 0,5)$ hastaya ise biyopsi endikasyonu konulmasına rağmen ailenin renal biyopsiyi kabul etmemesi üzerine biyopsi yapılamadı. Çalışma grubumuzda renal biyopsi yapılan 6 $(\% 2,9)$ hastada diffüz mezengial proliferasyon tespit edilirken $1(\% 0,5)$ hastada klas II lupus nefriti tespit edildi.

HSP'nin spesifik bir laboratuvar bulgusu yoktur. Döküntünün özelliğinin nontrombositopenik olması gereğince trombositopeninin olmadığı gösterilmelidir. Hastalarımızın \%27,4'ünde lökositoz, \%34,9'unda trombositopeni mevcuttu. Hastaların başlangıçtaki lökosit değerlerinin sistem tutulumu ve relaps ile ilişkisi değerlendirdiğimizde lökositoz ile renal tutulum ve GiS tutulumu arasında anlamlı bir ilişki saptarken diğer sistem tutulumları ve relaps açııından bu anlamlı ilişkiyi gösteremedik. Hastaların başlangıçtaki trombosit değerlerinin sistem tutulumu ve relaps ile ilişkisi değerlendirildiğinde ne sistem tutulumları ne de relaps açısından istatistiksel olarak anlamlı bir ilişki saptamadık. Çalışmamızda ayrıca laboratuvar parametreleri her bir yaş grubu ile ayrı ayrı istatistiksel olarak değerlendirildi. Buna göre, yaş grupları ile serum IgA düzeyi, beyaz küre sayısı, trombosit sayısı, eritrosit sedimantasyon hızı, serum CRP ve anti streptolizin O düzeyleri, hepatit B antijen pozitifliği, boğaz kültüründe $A$ grubu $\beta$ hemolitik streptokok üretilmesi ve gaytada gizli kan pozitifliği arasında herhangi bir istatistiksel anlamlı ilişki saptanmadı. HSP'nin seyri esnasında vakaların yaklaşık yarısında, serum IgA düzeylerinde artma, dolaşımda lgA içeren immün kompleksler ve damar duvarları ile renal mezengiumda IgA birikimleri saptanmaktadır. Literatürde serum IgA düzeyinin prognoza, organ tutulumuna ve relapsa etkisinin olmadığını bildiren yayınlar mevcuttur9,18. Yunanistan'da yapılan bir çalışmada 69 HSP'li hastanın 50'sinde $(\% 72,5)$ serum IgA düzeyi yüksek olarak tespit edilmiş ve bu 50 hastanın 16'sında (\%32) renal tutulum görülmüşken serum IgA düzeyi normal olan hastaların sadece 1 'inde $(\% 5,3)$ böbrek tutulumuna rastlanmıştır 19 . Vakalarımızda, serum IgA düzeyi $14(\% 6,6)$ hastada yüksek, $2(\% 0,9)$ hastada düşük, $67(\% 31,6)$ hastada ise normal olarak tespit edildi. Hastalarımızın 129'unda ise serum IgA düzeyi çalışılamadı. Çalışmamızda serum IgA düzeyi yüksekliği ile Gis tutulumu, renal tutulum ve relaps arasında anlamlı bir ilişki saptanmazken, serum IgA düzeyi yüksek olanlarda eklem tutulumunun daha sık olduğu görüldü. Bu birliktelik istatistiksel olarak anlamlıydı.

HSP atağı esnasında inflamasyon nedeniyle eritrosit sedimantasyon hızında artış olabilir20. Benzer şekilde bir pozitif akut faz reaktanı olan CRP'de diğer tüm vaskülitlerde olduğu gibi HSP'de de yüksek bulunabilir. Macaristan'da yapılan erişkin HSP'li hastaların dahil edildiği bir çalışmada kontrol grubu ile karşılaştııldığında akut faz esnasında serum CRP düzeyi anlamlı olarak yüksek bulunmuştur21. Tayvan'da yapılan bir başka çalışmada ise erişkin ve çocuklarda görülen HSP karşılaştırılmış, çocuklarda eritrosit sedimantasyon hızının daha yüksek olduğu ve bunun istatistiksel olarak anlamlı olduğu sonucuna varılmıştır22. İspanya'da yapılan benzer bir çalışmada da eritrosit sedimantasyon hızı yüksekliğinin çocuklarla karşılaştırıldığında erişkinlerde daha yüksek olduğu gösterilmiştir23. Çalışmamızda sedimentasyon hızı hastaların 82'sinde $(\% 38,7)$ yüksek olarak saptanırken, 80 hastada $(\% 37,7)$ hastada normal olarak değerlendirildi. $50(\% 23,6)$ hastada ise sedimentasyon hzı çalışılamadı. 212 hastanın 78'inde $(\% 36,8)$ CRP düzeyi normal iken 88 $(\% 41,5)$ hastada CRP düzeyi yüksek olarak tespit edildi. $46(\% 21,7)$ hastada ise CRP düzeyine bakılamadı. Biz CRP ve eritrosit sedimantasyon hızı yüksekliği ile Gis tutulumu, eklem tutulumu ve relaps arasında herhangi bir istatistiksel ilişki saptamazken her ikisinin yüksek düzeyleri ile renal tutulum arasında anlamlı bir ilişki olduğu sonucuna vardık.

HSP'de GiS kanaması, gaytada gizli kan testinin pozitifliği yanı sıra hayatı tehdit edecek boyutta da olabilir. Fretzayas A ve ark. ${ }^{11}$ yaptıkları çalışmada \%40,5 oranında gayta gizli kan tespit etmişlerdir. Chang WL ve ark.24 ise 261 hastanın 46'sında $(\% 17,6)$ Gis kanaması veya gayta gizli kan pozitifliği saptamışlardır. Bu oran bizim çalışmamızda elde ettiğimiz sonuca yakındı. Çalışmamızda gayta gizli kan pozitifliği ile sistem tulumları veya relaps arasında da anlamlı bir ilişki saptanmadı. Vakalarımız içinde toplam 212 hastanın 132'sinde $(\% 62,3)$ gaytasında gizli kan saptanmazken $46(\% 21,7)$ hastada gaytada gizli kan pozitif olarak saptandı. $34(\% 16,0)$ hasta ise gayta gizli kan çalışması için numune vermedi.

HSP sıklıkla iyi prognozlu ve kendiliğinden düzelebilen bir hastalık olduğu için çoğu zaman tedaviye gerek olmaz. Reamy BV. ve ark.25 çocukluk çağı HSP'nin \%94 oranında spontan düzelebilmesi nedeniyle destek tedavisinin ilk basamak olarak uygulanması gerektiğini bildirmişlerdir. Ayrıca abdominal ve eklem bulgularını rahatlatmak amacıyla 1-2 mg/kg/gün dozunda oral prednizon kullandıklarını bildirmişler. Yine aynı çalışmada steroidlerin çocuklarda abdominal ağrıyı rahatlatmada ve persistan renal hastalık gelişme oranını azaltmada faydalı olduğunu ileri sürmüşler ve ağır böbrek tutulumunda ise immunosupresanlarla birlikte yüksek doz steroid tedavisi önermişlerdir25. Peru H ve ark. ${ }^{12}$ GiS bulguları olan hastalara steroid tedavisi verilmesinin Gis kanama ve invajinasyon gibi muhtemel komplikasyonları önleyeceğine inandıklarını bildirmişlerdir. Aynı çalışmada nefrotik düzeyde proteinüri tedavisinde steroide ilave olarak siklofosfamid tedavisinin uygun yaklaşım olacağı bildirilmiştir. Marty $\mathrm{H}$. ve ark.'da26 kutanöz vaskülitlerde antihistaminik tedavinin düşünülebileceğini rapor etmişlerdir. Tayvan'da yapılan bir çalışmada da destek tedavinin yanında NSAii ve/veya steroidlerin kulanılabileceği bildirilmiştir27. Çalışma grubumuzda hastalar aldıkları tedavilere göre 4 gruba ayrılmışlardı. Tedavi süreleri hastaların klinik durumlarına göre 2 hafta ile 12 hafta arasında değişmekteydi. Kırk bir $(\% 19,3)$ hasta 1. grupta yer alırken $70(\% 33,0)$ hasta 2 . grupta yer almaktaydı. Kırk altı $(\% 21,7)$ hasta 3. grupta yer alırken $55(\% 25,9)$ hasta ise 4 . grupta yer almaktaydı. Hastalarımızın yaş grupları ile tedavi grupları arasında ve yaş grupları ile tedavi süreleri arasında korelasyon mevcuttu ve bu korelasyon istatistiksel olarak anlamlıydı. Hastalarımızın takiplerinde 182 'si $(\% 85,8)$ şifa ile sonuçlanırken, $5(\% 2,4)$ hasta ailenin isteği üzerine ileri merkeze sevk edildi. Yirmi beş $(\% 11,8)$ hasta ise ilk ataktan sonra kontrollere gelmediği için akibeti meçhul olarak değerlendirildi. Hastaların 46'sında $(\% 21,7)$ takiplerinde relaps gelişirken $166(\% 78,3)$ hastada ise relaps görülmedi. I. grupta $3(\% 1,4)$, II. grupta $21(\% 9,9)$, III. grupta $24(\% 11,3)$ hastada renal tutulum saptandı.

Sonuç olarak bu çalışma ile yaşın böbrek tutulumu ve dolayısı ile hematüri ve/veya proteinüri açısından risk faktörü olduğunu saptadık. 
Benzer şekilde hastaların başvuru esnasında beyaz küre sayısı yüksekliğinin böbrek ve GiS tutulumu açısından, serum IgA düzeyindeki artışında eklem tutulumu açısından risk faktörü olduğunu ortaya koyduk. Eritrosit sedimantasyon hızı ve CRP'nin yükselmesinin de renal tutulum açısından risk faktörü olduğunu saptadık. Hastaların yaşlarının arttıkça tedavi sürelerinin arttığını ve kombine ilaç tedavisine (antihistaminik, NSAil ve steroid) ihtiyacın arttığını gösterdik.

\section{Kaynaklar}

1. Gardner-Medwin JM, Dolezalova P, Cummins C, et al. Incidence of Henoch Schonlein purpura, Kawasaki disease, and rare vasculitides in children of different ethnic origins. Lancet 2002; 360: 1197-202.

2. Cassidy JT, Petty RE. Leukocytoclastic vasculitis. In: Textbook for Paediatric Rheumatology. Ed. Cassidy JT, Petty RE, Laxer RM, Lindsley CB. Philadelphia, Elsevier, Saunders company, 2005:496-511.

3. Mills JA, Michel BA, Bloch DA, et al. The American College of Rheumatology 1990 criteria for the classification of Henoch-Schönlein purpura. Arthritis Rheum 1990;33:1114-21.

4. Nong BR, Huang YF, Chuang CM, Liu CC, Hsieh KS. Fifteen-year experience of children with Henoch-Schönlein purpura in southern Taiwan, 1991-2005. J Microbiol Immunol Infect 2007:40:371-6.

5. Farahnak A: Childhood Henoch-Schonlein Nephritis A Multivariate Analysis of Clinical Features and Renal Morphology at Disease Onset. Iranian Journal of Kidney Diseases 2009; 3:17-21.

6. Kaku Y, Nohara K, Honda S. Renal involvement in Henoch-Schönlein purpura: a multivariate analysis of prognostic factors. Kidney Int 1998;53:1755-9.

7. Uppal SS, Hussain MA, Al-Raqum HA, et al. Henoch-Schönlein's purpura in adults versus children/adolescents: A comparative study. Clin Exp Rheumatol. 2006;24:26-30

8. Miller ML, Pachman ML: Vasculitis Syndromes. Ed. Kliegman RM, Behrman RE, Jenson HB, Stanton BF. Nelson Textbook of Pediatrics, WB Saunders Co, Phiadelphia, 2007;1042-49.

9. Saulsbury FT: Henoch-Schönlein purpura in children report of 100 patients and review of the literature. Medicine 1999;78:395-409.

10. Ozen S, Ruperto N, Dillon MJ, et al: EULAR/PReS endorsed consensus criteria for the classification of childhood vasculitides. Ann Rheum Dis 2006;65:936-41.

11. Fretzayas A, Sionti I, Moustaki M, Papadimitriou A, Nicolaidou P: HenochSchönlein purpura: a long-term prospective study in Greek children. J Clin Rheumatol 2008;14:324-31.
12. Peru H, Soylemezoglu O, Bakkaloglu SA, et al: Henoch Schonlein purpura in childhood: clinical analysis of 254 cases over a 3-year period. Clin Rheumatol 2008;27:1087-92.

13. Bulun A, Topaloglu R, Duzova A, et al: Ataxia and peripheral neuropathy: rare manifestations in Henoch-Schönlein purpura. Pediatr Nephrol 2001;16:1139-41.

14. Balmelli C, Laux-End R, Di Rocco D, Carvajal-Busslinger MI, Bianchetti MG: Schoenlein-Henoch purpura: course in 139 children. Schweiz Med Wochenschr 1996;126:293-8.

15. Rigante $D$, Candelli M, Federico $G$, et al: Predictive factors of renal involvement or relapsing disease in children with Henoch-Schönlein purpura. Rheumatol Int. 2005;25:45-8.

16. Saulsbury FT: Epidemiology of Henoch-Schönlein purpura. Cleve Clin J Med 2002;69:87-9.

17. Kawasaki $Y$, Suzuki J, Sakai $N$, et al: Clinical and pathological features of children with Henoch-Schoenlein purpura nephritis: risk factors associated with poor prognosis. Clin Nephrol 2003;60:153-60.

18. Ece A, Gürkan F, Haspolat K, et al: Henoch-Schönlein purpuralı çocuklarda renal ve gastrointestinal tutulumla ilişkili klinik ve laboratuvar bulgular. Çocuk Sağlığı ve Hastalıkları Dergisi 2000;43:36-42.

19. Fretzayas A, Sionti I, Moustaki M, Nicolaidou P: Clinical impact of altered immunoglobulin levels in Henoch-Schönlein purpura. Pediatr Int 2009;51:381-4.

20. Van Es LA, Kauffmann RH, Valentijn RM. Henoch-Schönlein purpura. Ed. Holliday MA, Barratt TM, Vernier RL. Pediatric Nephrology. Baltimore Williams Wilkins, 1987;492-8.

21. Novák J, Szekanecz Z, Sebesi J, et al: Elevated levels of anti-Helicobacter pylori antibodies in Henoch-Schönlein purpura. Autoimmunity 2003;36:307-11.

22. Hung SP, Yang YH, Lin YT, et al: Clinical manifestations and outcomes of Henoch-Schönlein purpura: comparison between adults and children. Pediatr Neonatol 2009:50:162-8.

23. Blanco R, Martínez-Taboada VM, Rodríguez-Valverde V, García-Fuentes M, González-Gay MA: Henoch-Schönlein purpura in adulthood and childhood: two different expressions of the same syndrome. Arthritis Rheum 1997:40:859-64.

24. Chang WL, Yang YH, Lin YT, Chiang BL: Gastrointestinal manifestations in Henoch-Schönlein purpura: a review of 261 patients. Acta Paediatr 2004;93:1427-31.

25. Reamy BV, Williams PM, Lindsay TJ. Henoch-Schönlein purpura. Am Fam Physician. 2009;80:697-704.

26. Marty H, Mazzucchelli L: Cutaneous vasculitis: how to recognize, interpret, treat it? Schweiz Rundsch Med Prax 1994;83:240-5.

27. Huang DC, Yang YH, Lin YT, Chiang BL: Cyclosporin A therapy for steroiddependent Henoch-Schönlein purpuraJ Microbiol Immunol Infect. 2003;36:61-4. 